\title{
旧式燒酎の収得歩合についで [3]
}

\author{
加藤 百 一 \\ (昭和 31 年 12 月 8 日受理)
}

先に熊本局管内に於ける旧式焼酎の製造工場 427 場を対象として, 工場の年間収得歩合を重点的に調查し

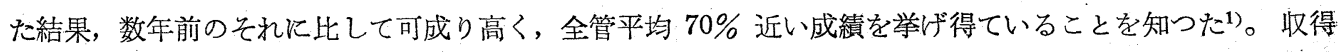
歩合の上昇は必ずしも焼酎の品位向上の決定的条件ではないが，旧式焼酎に於ては品位的に優れたもの程， この歩合が幾分高い傾向を全く否定することは出来ない。従つて収得歩合の向上に留意することは焼酎製造 の基本であると共に，又新式焼酎伍して市場価值をより高める手段の一つと考穴られる。

斯る意味もあつて, 今回は調査の対象を工場の年間製造高単位ではなくて, 製品そのるのに向けた。即ち 昭和 30 酒造年度産旧式焼酎 617 点**について, 各焼酎の品位ならびに収得歩合, 更に此等に関連して二, 三の製造諸元を調查した。本報はこれ等の結果を焼酎の原料別に要約して報告する。

\section{調 查 事 項}

\section{I. 原料别に見た旧式焼酎の収得歩合}

\section{A. 旧式焙酎の種類と歩留との関係}

旧式焼酎は原料により香味的な特色が認められるので, 産地等を考慮しなければ原料別に分類するのが普 通である。南九州で焼酎とい衤ば芋焼酮が主体であるが，今回は主原料***により旧式燒酎を第 1 表の如く 分類****した。

本報で焼酎の収得歩合 ( 歩留) とは供試焼酎をふくむ一検定分界のそれを意味する。即ちその分界内で使 用した原料の総有效成分から理論上のアルコール個数を算出し, これに対して実際製成された焼酎のアルコ ール個数の割合を 100 分比で表わした。この場合使用原料の有効成分, 即ち澱粉価等は前報 ${ }^{1)}$ と全く同様に 計上した。その結果第 1 表の如き歩留成績を得たが，この表は同時に旧式焼酎の原料別歩留の分布頻度をも 揭げた。

第 1 表 原料別に見た旧式焼酎の歩留

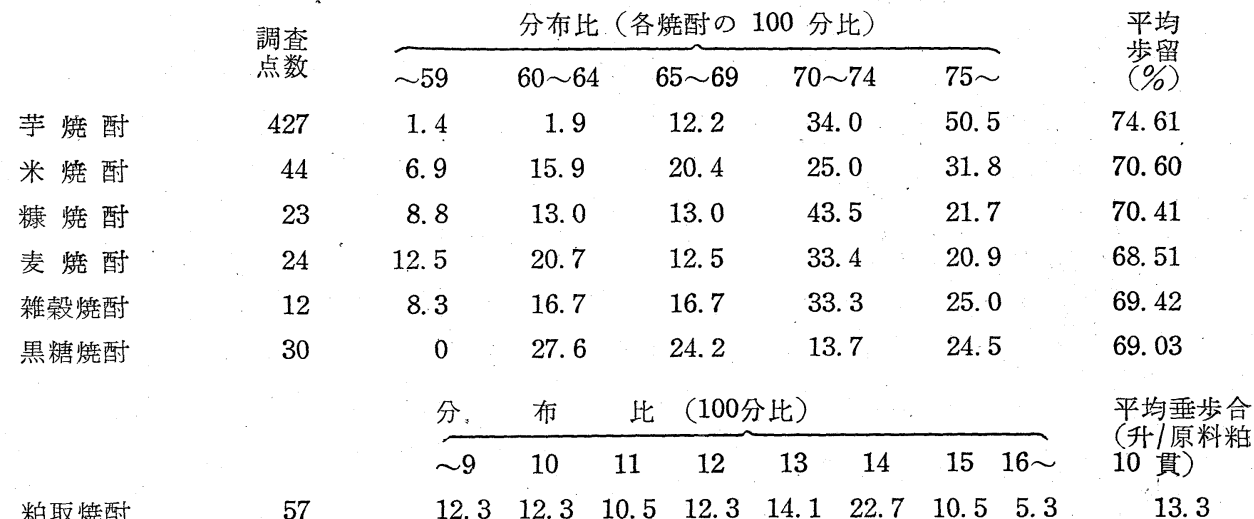

\footnotetext{
* 本稿の一部は昭和 31 年 11 月 11 日全国鑑定官会議研究報告会に於て口演

* 昭和 31 年 5 月熊本局管内庫内鑑査会出品酒

** 米渵酎には白棣を, 糠焼酎には麦類, 玉蜀㯟等を一部併用したものを含めた。又雑穀焼酎の大部分は高 粱を原料とするが，粟，玉蜀黍のものもこの中に含めた。併し何れにしても二，三の例外を除いては猌 は凡て外 (砕) 米を使用している。

*** 山田博士2) は旧式燒酎を粕取, 米, 球磨 (熊本県人吉市を主産地とする米焼酎), 麦, 甘諸, 雑原料 (白 棣, 団栗, 甘諸搾汁, 菊莳等) 焼酎に, 著者 ${ }^{3}$ は南九州地方の焼酎を米, 球磨, 麦, 大島, 芋, 粕取接 酎の 6 種に分類した。
} 
1) 旧式焼酎の歩留は全般的にみて良好で，歩留 $60 \%$ 未満の低率焼酎は全試料のわずか $2 \%$ を占めるに 過ぎず，全体の 4 割 5 分までが歩留 $75 \%$ 以上，更に歩留 $70 \%$ 以上の高率焼酎は実に全体の 8 割近くを占め る好成績を挙げている。供試焼酎 560 点（粕取狫酎を除く）の総平均歩留 $73.44 \%$ とい5成績は既往 2 ,4 9) 文献り何れに比しても可なり良好である。この事は順調な気候, 充実した原料, その他諸種製造条件に恵ま れた為であるが，それにもるして酸管理に適切な注意が払われ，有害菌による污染が極めて少なかつたもの と解せられる。

2）旧式焼酎の収得歩合の分布頻度は原料により特色が認められる。即ち第 1 表に見られる如く芋及び米 焼酎は歩留 $75 \%$ 以上を, 黑糖焼酎以外の他の焼酎は何れも70 74\%を頂点として, 各々の分布曲線は低歩 留の方向に或いは急に, 或いは緩やが流れている。又これ等歩留の分布限界は芋焼酶が最る広く, 糠, 麦 及び黑糖燒酎等は比較的狭い。

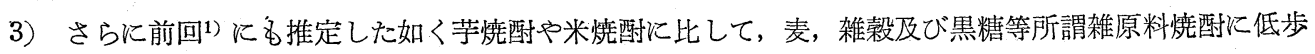
留のものが多い事は注目すべきである。これは雑谼, 雑原料の処理の因難さに負わすべきではなくて, むし ろ此等の原料を主とする工場の醪管理, さらには蒸溜機及びその行程に今後の改善が残されているぬのと思 考される。

4）粕取燒酎の垂歩合は原料粕 10 貫当り平均 13.3 升で, その最高限界は 18.4 升であつた。しかも全 体の 6 割 5 分は 12.0 升以上の好成績を示した。これは前年度成績3)を上廻り, 成書2)のそれよりはるかに 良好な成績であつた。

\section{B. 旧式焼酎の収得歩合と品位の関係}

唎酒成績から芋焼酎を A, B , C, 他焼酎を A, C の三或いは二群に分け, 各 group に於ける歩留の分布割 合(100 分比) を原料毎に調查した結果が第 1 図である。な技図中カッコ内の数字は各群の平均歩留を示す。

第 1 図旧式烓酎の収得歩合と品位との関係

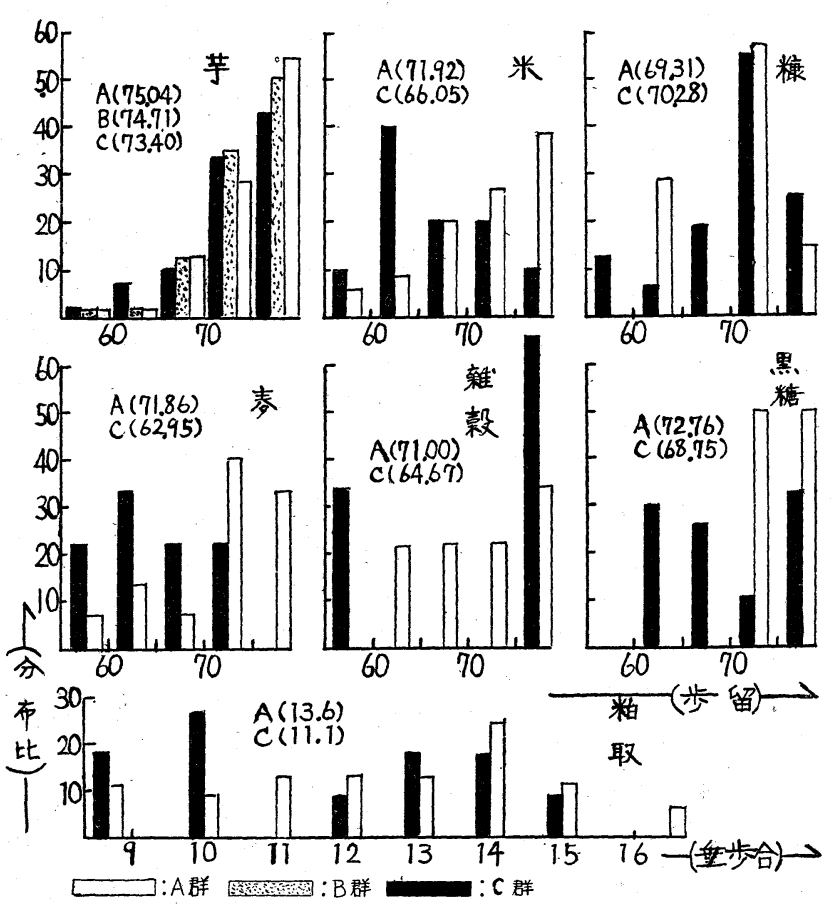

1）糠焼酎以外は何れの焼酎子収 得歩合と品位との間には略並行的関 係が認められる。即ち上位群に高歩 留のものが多く, 且一般に平均歩留 も高い傾向がある。然るに芋焼酎は この傾向が余り明かではない。又糠 焼酎はこれ等一般的傾向とは逆に, 下位群に高歩留のものが多いが，両 群の平均歩留は大差がない。このこ とは步留の上昇は品位向上の目安に はなるが，必ずしも決定的条件では ないという前報1,3) の推定を裏付け ることにはならないだろらか。換言 すれば步留と品位とはめる程度まで は並行的に上昇するが，それ以上に なると却つて風味が単調になり易い ことは実地製造上屢々体験する所で ある。従つて旧式焼酎の製造に当つ ては歩留を高めるのは勿論必要であ るが，風味を落さない end point を 握むことが今後我々に与兄られた大 きな課題といえよう。

2）粕取焼酎の品位と垂歩合との関係は第 1 図に見られる如く, 前報3) と殆ど同一結果が認められた。

\section{II. 醪取焼酎の製造諸元}

旧式焼酎, 特に醪取焼酎は後述の如き理由から, 焼酎の品位或いは収得歩合を重点とする製造諸元, 即ち 一次, 二次仕込の製造条件或いはその経過等を適確に把握するのは実際的にはなかなか困難である。従つて この場合製造諸元と言つても種憗菌の種類や石当りの使用量, 更には楼歩合とか汲水歩合等の如く, 主とし 
て製造歩合についての調査に止めた。此等の結果は原料毎に取りまとめて第 $2 \sim 9$ 図に示した。第 2 図以下 芋焼酎はHが歩留 75步上上，Mが 74〜70\%，Lが 70\% 未満の各群を，その他の焼酎はHが歩留 70\% 以 上，Lが 70\% 未満を表わしている。唎酒成績による各群の表示は前節 Bに示した如くである。なお第 3 9 図は何れも上段に歩留別, 下段に品位別の分布頻度を揭げ, 縦軸に分布比 (\%) を, 横軸には各製造諸元 を採り,カッコ内の数值は各製造諸元の平均值を示した。

\section{A. 種䊩}

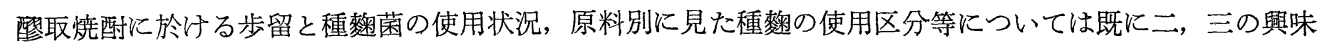

第 2 図鵤種菌の使用割合

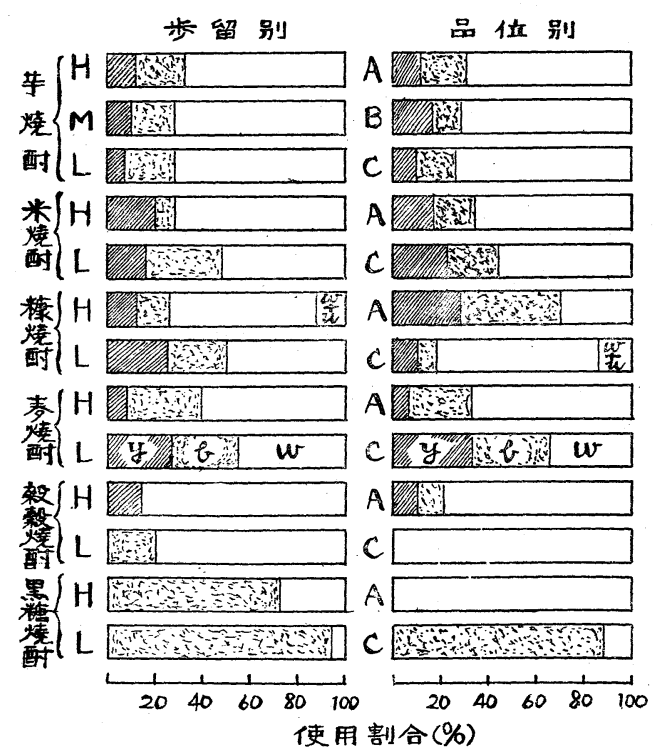

ある知見 ${ }^{1,3)}$ を得たが，な括これ等の関係について 詳細なる調查を行い，第 2 図にその結果を図示し た。図中 $y$ は黄楼菌, $b$ は黒麴菌, $w$ は白麴菌, $w$ $+u$ 注白麴菌と宇佐美菌の併用を示す。

1）白麭菌の使用は益々増加し，黑糖焼酎を除い ては何れの焼酎る 5 割以上の使用比を示している。 特に雑嘻燒酎と芋燒酶はこの傾向が顕著で, 前者は その 8 割, 後者はその 7 割が白麭菌を使用している。 更に注目すべき傾向は奄美大島の黒糖焼酎で, 前酒 造年度まで黒棣菌一辺倒であつたのが，今回の調查 にはその 2 割近くが白楝菌を試用して良成績を挙げ ていることである。

黄䊝菌は原料の如何に拘らず, 使用割合は各々の 2 割汇も満たなかつた。併し米焼酎などは風味の点

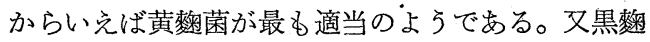
菌の使用割合は黑糖燒酎の 8 割, 麦焼酎の 3 割以外 は何れの焼酎も各々の 2 割にも充たなかつた。併し 最も旧式焼酎らしい風格を持つているのは矢張り黒 楝菌を使用したものではなかららか。

2）芋焼酎の外は何北の焼酎も高歩留群が白麴菌の使用割合が多く，これに比して黄麴菌や黒椈菌の使用 割合は少なかつた。又米, 麦及び黒糖焼酎の上位群は下位群に比して白麴菌の使用割合が滛が多い。併し これ等の知見から直ちに白麳菌を使苀ば品位も向上し，又歩留も良くなるという結論を抽き出すのは早計で める。

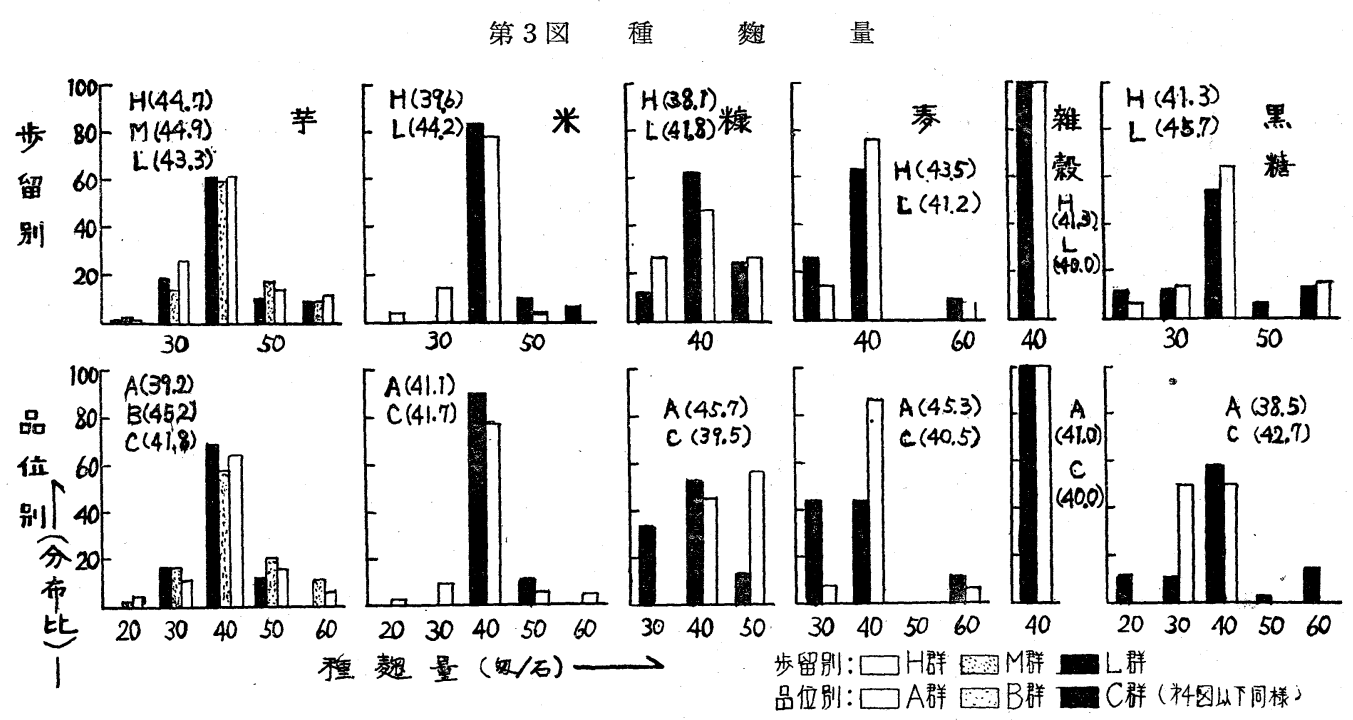


何となれば芓焼酎の高歩留群は却つて黄㮃菌の使用割合が多く, 又芋焼酶は高歩留群より低步留群ほど,

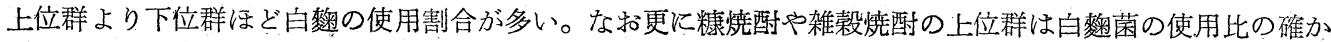

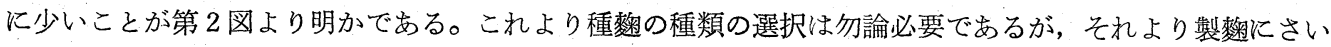

して各々種㹼の特性を充分生かして, 爾後の管理を行うことが品質的にも歩留向上の為にも望ましい。

3）原料の如何に拘らず, 種麴の使用量は石当 40 多程度のものが最も多く, 芋, 米及び雑䪄焼酎は各々 の 7 割以上を, 其の他の焼酎は各々の半数を占めている。所が芋焼酎や麦焼酎の中には石当 120 多も使つて いるものが見られた。

4）種憗量の多富は步留と直接的関係はないとしても, 第 3 図より概して高歩留群は種麴量の少いものが 多い傾向が認められた。而るに芋焼酎や麦焼酎は却つて低歩留群は種策量の少いものが稍多いが，その差異 は極めて些少であつた。

5）糠焼酎と麦焼酎を除いては何れも上位群は種楼量が少く，且少なるものが多い傾向が認められた。

B. 齿歯

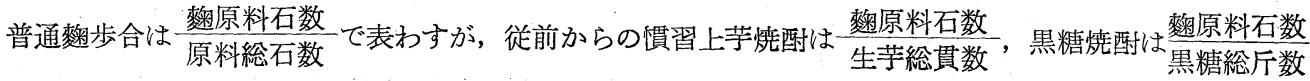

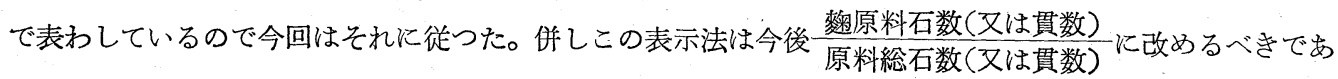
る。

1）芋焼酎は品位の優劣, 歩留の高低に拘らず各 group の 8 割以上が 5 割楼で, その分布範囲は可なり 広く $3.3 \sim 12.1$ 割楼である。而して上位群はその分布幅も狭く, 且平均釉歩合が小さいのは注目すべき点 である。

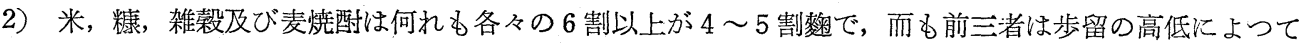
大差は見られないが，麦焼酎は低歩留群に䴹歩合の少いものが多い傾向は第 4 図で明かに見られる。

3）黑糖焼酎は黒糖 100 斤に対して 3.5 割麥以下が普通であるが，泡盛式と称して6〜20 割㹼にするこ

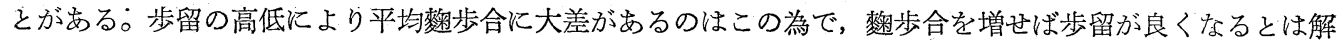

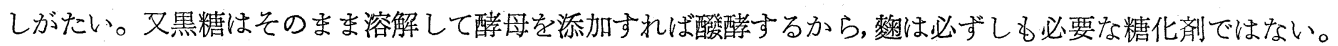
従つて米は米楼としてょり, 焼酎に丸味をあたえる調味剤としての役割も忘れてはならない。故に泡盛式黒 糖焼酎は矢張り米を多く使用する方が効果的であろう。

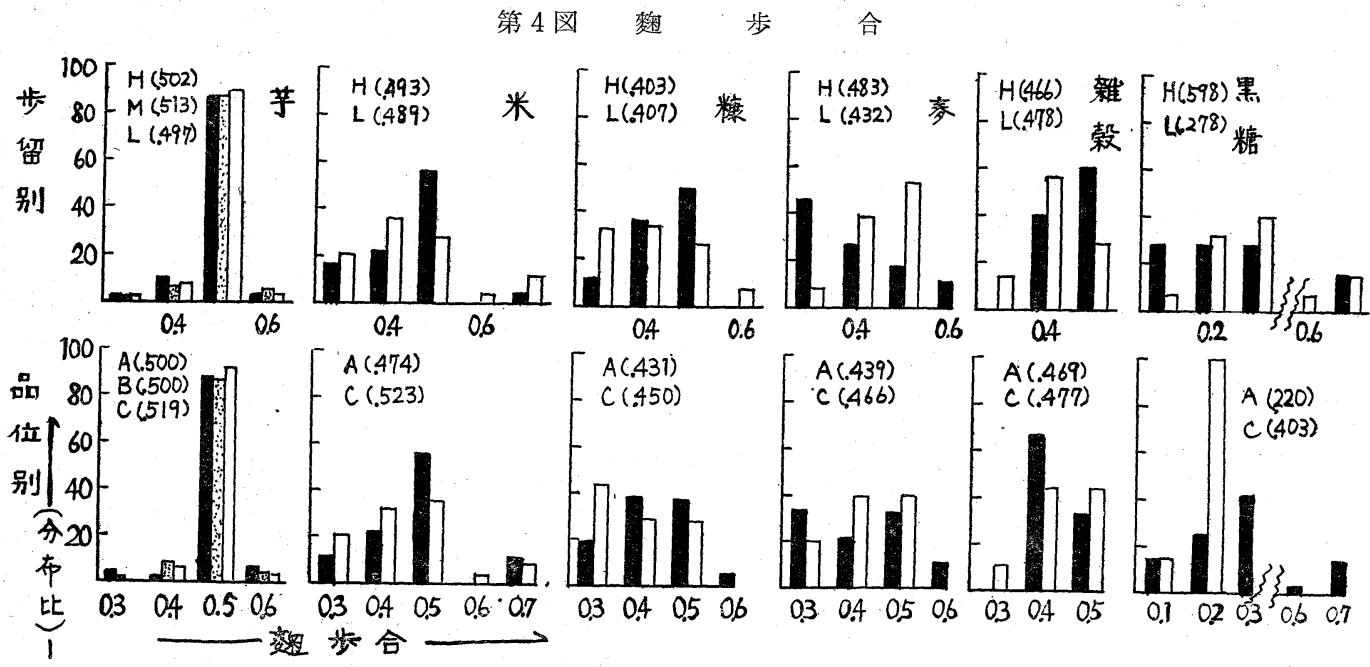

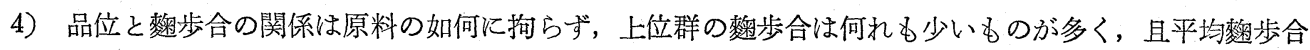
も少い。このことは上位群及び高歩留群が概して種宷量が少なく，且少なるものが多いという前項 3)，4） の知見と思い合せてはなはだ興味深い。

\section{C. 仕込. 方 法}

通常旧式焼酎の仕込方法は二段仕込で，麴は一次仕込のみに使用し，主原料は二次に掛ける。所が時には 主原料を清酒仕込の如く二回，三回に分けて掛けることがある。 
1）芋焼酎の主産地鹿児島，宮崎県地方に於ては一次に鯬のみを使用し，二次仕込に生芋の全量を掛ける 所謂二段仕込法が普通であるが，生芋を二回に分割して掛ける三段仕込を採つたものが調査点数 427 点中 1 点あうた。

2) 米焼酎も亦清とんぞ二段仕込で, 三段仕込は 44 点中 1 点に過ぎない。

第 2 表旧式燒酎の仕込方法

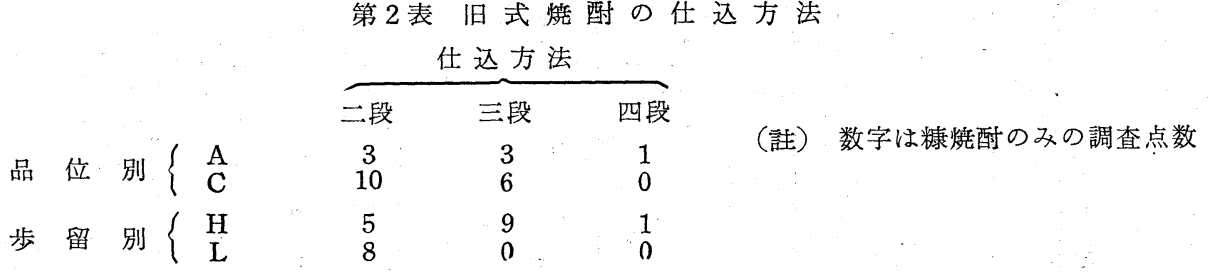

3）糠焼酎は第 2 表に表示せる如く二段仕込によるものが略半数, 三段以上の仕込法（清酒式にい兄ば酒 母, 添, 留の三段）を採るものが他の焼酎に比して压倒的に多かつた。二段仕込と三段仕込とが品位に及涪 す影響は判然としないが，後者の仕込法によるものは歩留的に良成績を挙げているのは興味深い。このこと は野白氏9）る実験室的に確認している。

4）其の他麦，雑䍍及び黒糖哑酎は凡て二段仕込法汇依る。

D. 泥水歩合

一般に汲水歩合は $\frac{\text { 汲水総石数 }}{\text { 料総石数 }}$ 表わすが, 芋狫酎の主産地である鹿児島, 宮崎県に於ては従前より一次 仕込の麯原料石数を neglect して生芋貫数（この場合生芋 100 貫を1石と見なして）に対する一次，二次

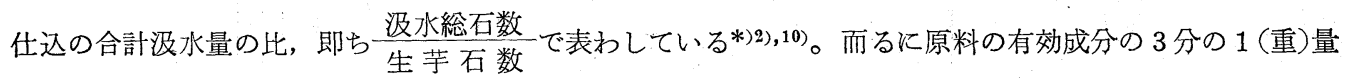
は少くも麭米に由来するので, 歩留から見れば麴米を neglect して汲水歩合を算出するのは不合理である。 従つて本報では便宜上生芋 100 貫を1石とし，これに粨米の外 (砕) 米石数を合算して 汲水総石数

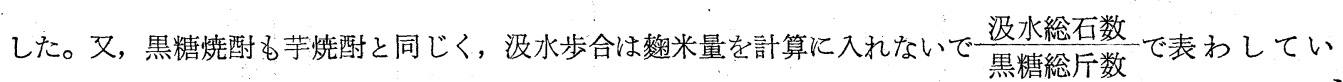

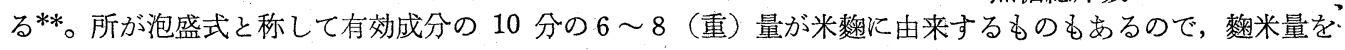
neglcet するのは合理的でない。従つてここでは黒糖 100 斤を1石と見なして，これに䊍米量を加えて 汲水総石数

1) 第 5 図に示すよ5に芋焼酎の約 8 割むでが 10 水（生芋に対しては 15 水）を没み, 品位の優劣, 歩 留の高低による総汲水歩合の差異は殆んど認められない。然るに詳細に見れば第 6 図の如く 1 次仕込の汲水 歩合, 即ち摰米に対する汲水はその 8 割までが 10 水である。な怙, 高歩留群程没水の延びたるのが多く, 上位群ほど汲水を詰めたものが多い傾向は，此等の差異が数字的には些少であつても見のがし難い。

更に二次仕込の汲水歩合は第 7 図に見られる如く上位群程或いは高歩留群ほど大なるすのが多い。勿論こ れ等の差異はごく僅少であるが，それにしてもこの傾向は実地製造上体験され，極めて興味ある知見であつ た。

2）米焼酎の総没水量はその 7 割が 10 11 水である。高歩留群は汲水の延びたものが多く, 特にその 3 分の 1 が 12 水以上であつたのは注目すべきである。一次仕込の汲水量は第 6 図に見られる如く, 品位的或 いは歩留的差異は殆んど認めがたいが，二次仕込の波水歩合は上位群が下位群に比し，高歩留群が低歩留群 飞比して何れも大きく，且つ汲水の延びたものが多い傾向は第 7 戝より認められる。

3）糠焼酎の一次, 二次仕込の汲水歩合, さらに総汲水量は品位, 歩留の如何に拘らず，各 group の約

* 芋焼酎は下記の如き仕込配合の場合，米麭 5 斗分を除いて 15 水とい 3 が，本報の算出法よりすれば 10 水となる。

\begin{tabular}{|c|c|c|c|}
\hline 外(砵)米 & $\begin{array}{c}\text { 第 1 次 } \\
500\end{array}$ & 第 2 次 & $\begin{array}{l}\text { 合 計 } \\
500 \text { (合) }\end{array}$ \\
\hline 生 芋 & & 100 & 100(貫) \\
\hline 波 & 500 & 1,000 & 1,500 (合) \\
\hline
\end{tabular}

** 従前より奄美大島に於ては黒糖 100 斤（16 貫）を1石と見なし，これに水 1 石汲めば楚米量の如何に 拘らず 10 水といつた。 
第 5 図 総 没 水 歩 合
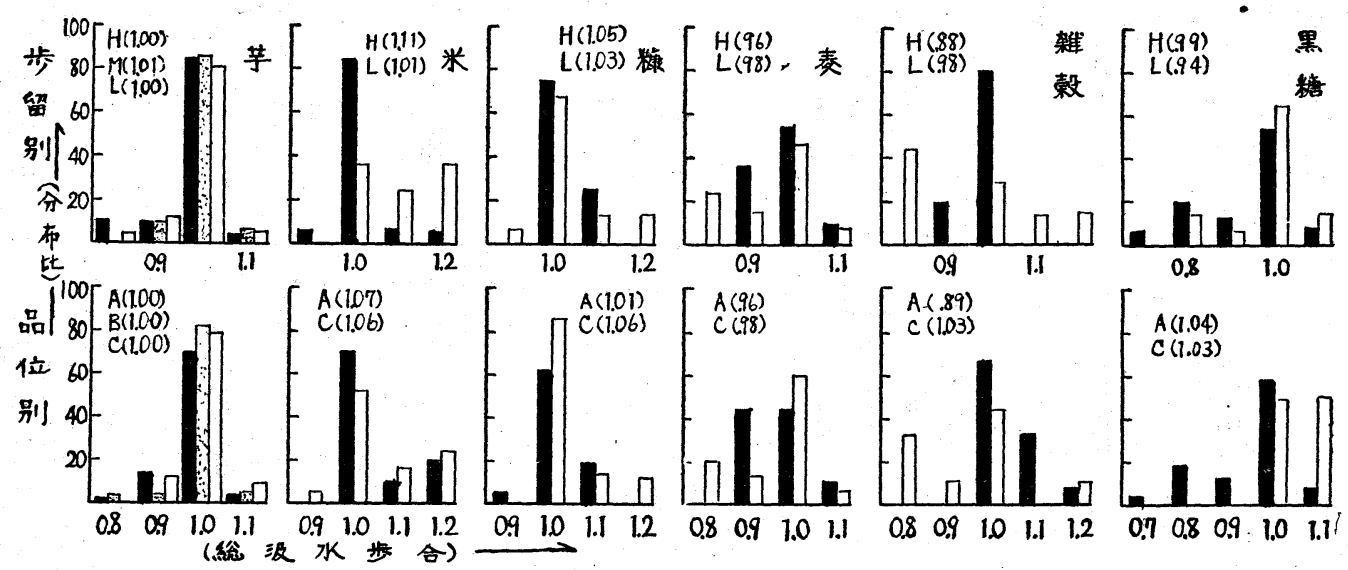

第 6 図一次仕込の汲水歩合
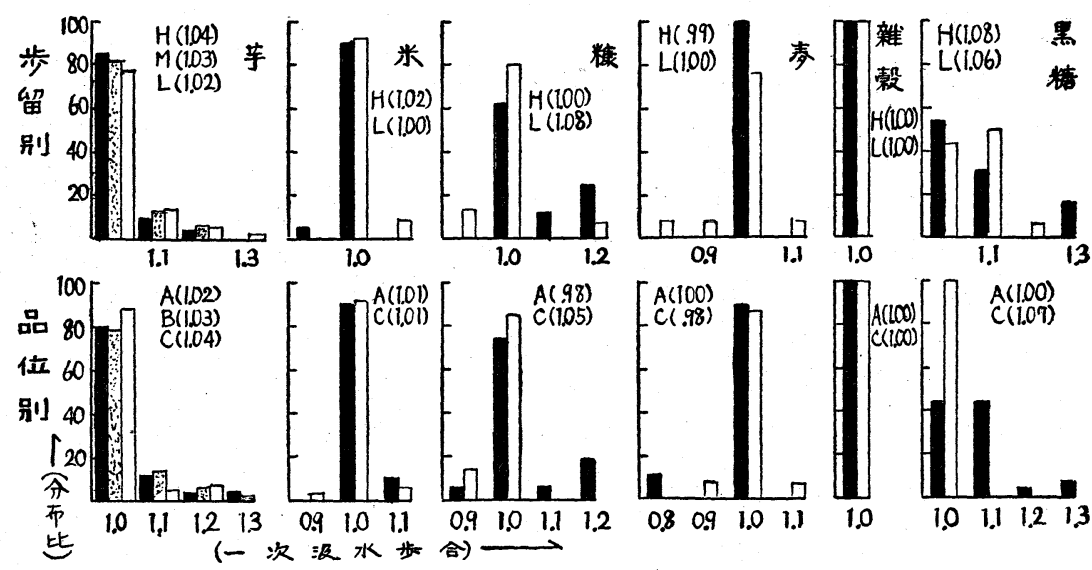

第 7 図二次仕込の没水歩合

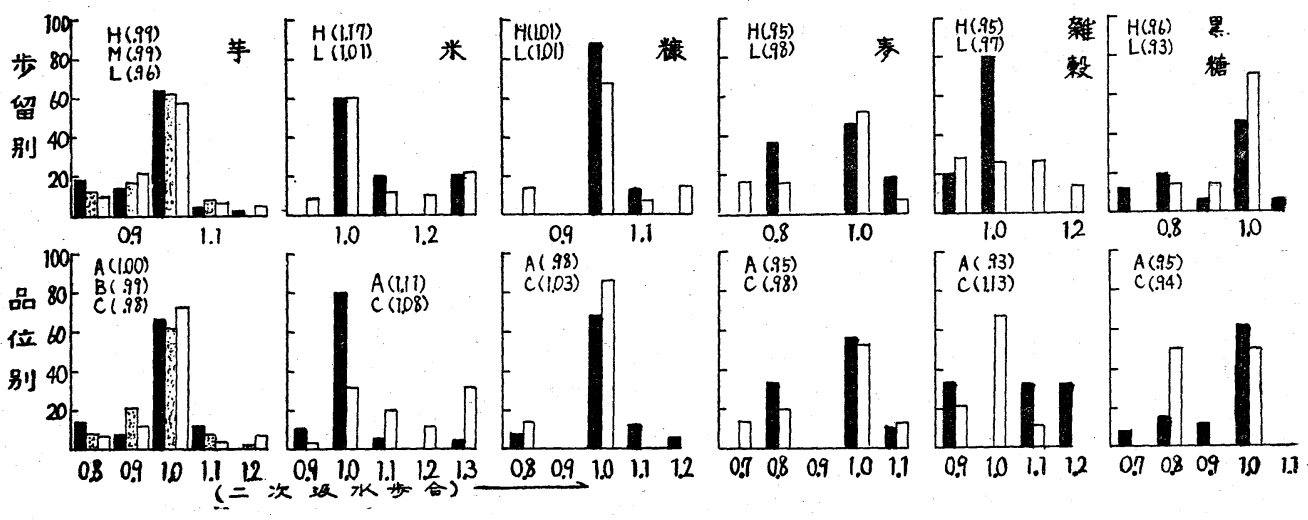

7 割が 10 水である。品位的に見れば上位群の総波水歩合及び二次仕込の汲水歩合は小さいものが多いが, 収得歩合と汲水量との関係は判然としない。

4）麦焼酎の略半数が 10 水である。麦焼酎の上位群は下位群に比し, 高歩留群は低歩留群に比して総汲 水歩合, 一次ならびに二次仕込の汲水歩合は何れる小さい傾向が第 5, 6, 7 図上り認められる。

5）雑谼焼酎の一次仕込は釉米に対して殆ど 10 水であるが，二次仕込は 4.1 13.6 水, 総汲水步合は 
5. 6 12.4 水と, その分布は可なり広範囲にわたつている。更に雑殼焼酎は品位的にも歩留的にも麦焼酎と 全く同一傾向を示した。

5）黒糖焼酎の略 3 分の 2 は 10 11 水である。高歩留群の全汲水歩合，一次及び二次仕込の波水歩合は 何れも大なるものが多く, 且つ平均歩合も大である。品位的にも上位群は汲水を延したものが多いが, 二次

第 8 図 熟 成 歩 合
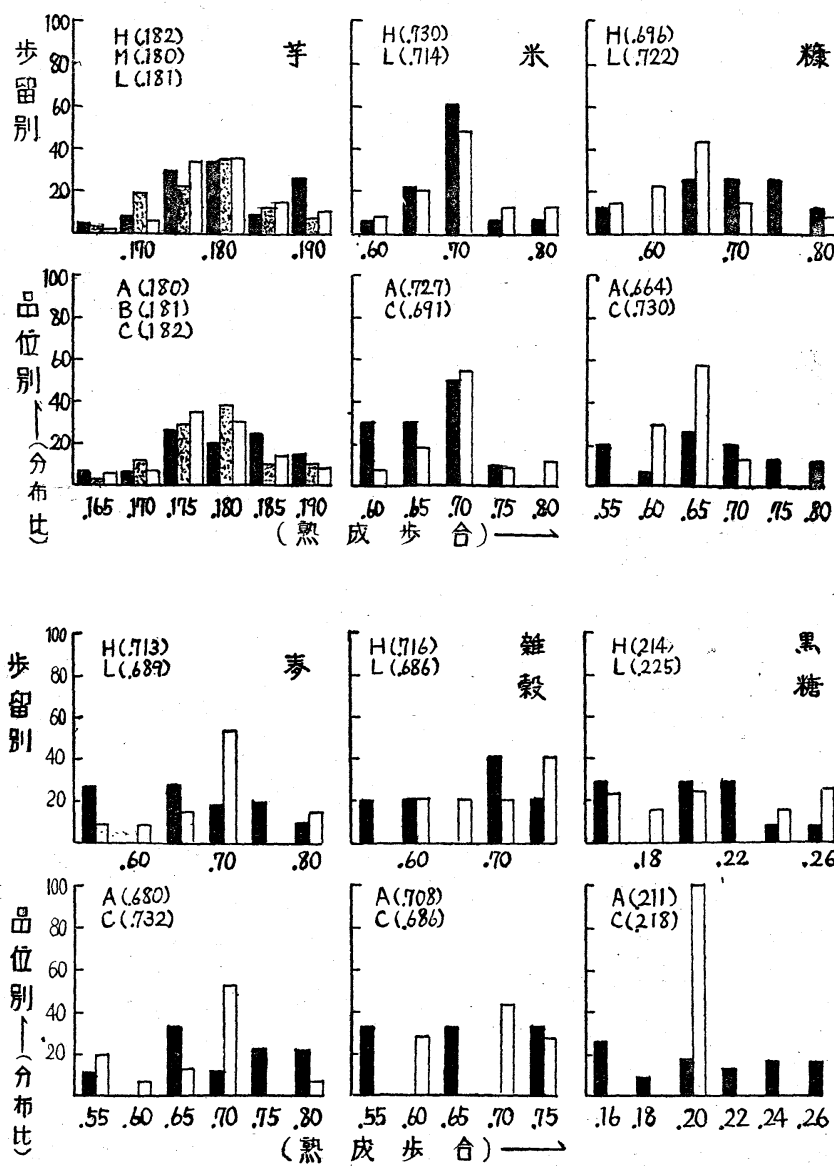

仕込のそれは却つて波水をつめたも のが多いのは興味深い。

糖

E. 熟成歩 合

1）旧式焼酎の熟成歩合* は第 8 図に見られる如く仕込原料に依つて 特長が見られる。即ち芋焼酎の 8 割近くが $0.175 \sim 0.184$, 雑豰焼酎 0.75 前後, 米焼酎 0.7 , 黑糖焼酎 0.2 以上に各々の約 7 割が分布して いる。その他の焼酎は略その半数が 0.7 を占めていた。

2）熟成歩合と歩留の関係につい ても第 8 図に見られるように原料に よつて特異的である。即ち芋焼酎の 熟成歩合は歩留の高低により判然た る差異は認めがたいが, 米, 麦及び 雑穀焼酎等の高步留群は各々の低歩 留群に比して, 平均熟成歩合は何れ も幾分大きく，且歩合の大なるもの が多い。これに反して糠及び黒糖焼 酎の高步留群は却つて平均步合子小 さく, さらに小なるものが多い傾向 が認められる。

3）品位的に見れば麦焼酎以外の 焼酎の熟成歩合は 2) と同一傾向が 認められる。而して麦焼酎の熟成歩 合は歩留の場合と逆に, その下位群 に比して上位群のそれの方が平均步

合も少であつた。

F. 醊 酵 歩 合

䣯酵歩合は仕込原料の総有効成分から理論上製成されるはずの酒精総個数を算出し，これに対して実際に 生成された焼酎の鋉の酒精総個数の割合を 100 分比で示した。

1）旧式焼酎の䤑酵平均歩合は可成り高く, 芋焼酎の $76.0 \%$, 次いで糠焼酎の $74.7 \%$, 米焼酎の 73.0 $\%$, 麦焼酎の $72.4 \%$, 雑㩆焼酎の $71.8 \%$, 黒糖焼酎の $71.7 \%$ で, 最低の雑穀及び黒糖焼酎でも $72 \%$ 近い 好成績を挙げている。

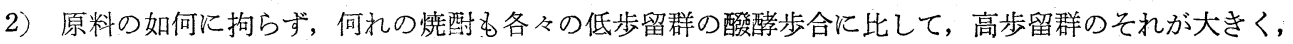
且大なるものが多い。この傾向は第 9 図より指摘され得る。

3）醱酵歩合が $75 \%$ 以上女つたのに拘らず歩留が $70 \%$ ねるものが芋及び米焼酎は各々の約 1 割, 麦及 び黒糖焼酎はそれぞれの 2 割近く，更に糠焼酎に於ては実にその半数もあつた。これは明かに蒸溜機そのる

\footnotetext{
*熊本局に於ける基準熟成歩合ならびに昭和 27,28 両酒造年度の実績は次のようである。

\begin{tabular}{|c|c|c|c|c|}
\hline 原 料 & 基準歩合 & 昭27酒 & 昭28酒 & 昭 29 酒以降 \\
\hline 米・雑殼 & 0.700 & 0.705 & 0.728 & 前年度実積 \\
\hline 生＼cjkstart芋 & 0.145 & 0.175 & 0.180 & 11 \\
\hline 其の他の原料 & 前年度実績 & 一 & - & "l \\
\hline
\end{tabular}
}




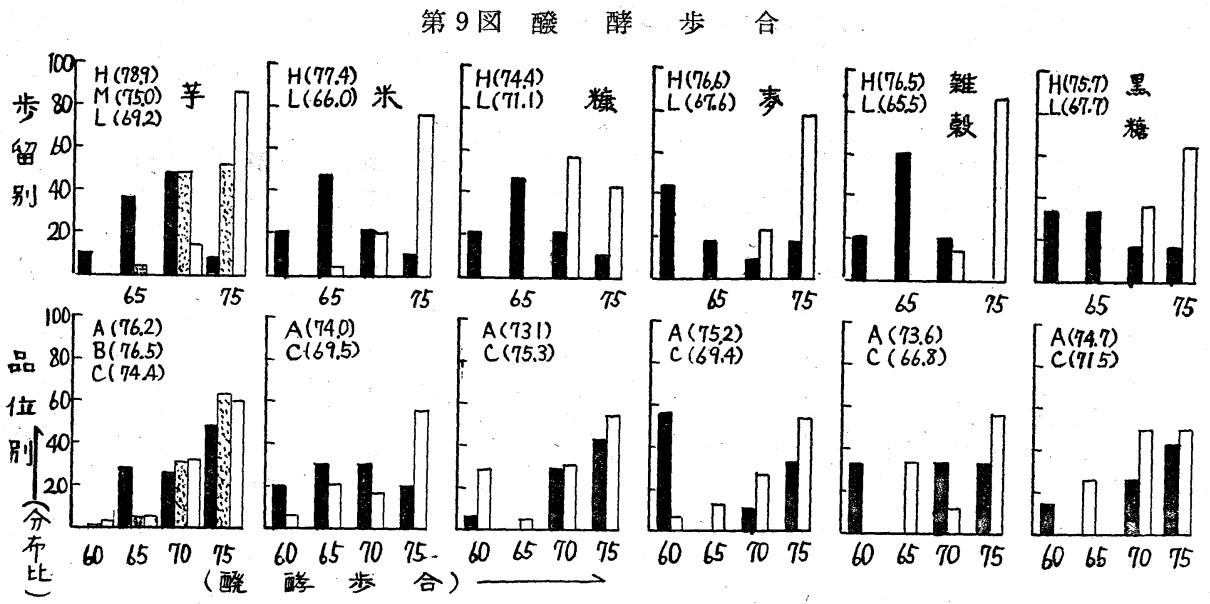

のの不備, 或いは蒸溜時に於怢失敗, 更に不注意による損失に起因するるので, 今後の蒸溜機の改善及 び蒸溜のさいに物ける十分なる注意が望まれる。

糠炸酎を除いた他の焼酎は何れも上位群の酸酵歩合が下位群のそれに比して高く，且つ高いるのが多い。 この傾向は前述の歩留との関係の場合と殆ど同一でめる。

\section{III. 粕取焼酎の製造諸元}

粕取洷酎の垂歩合及び品位と製造諸元との関係ば前回 ${ }^{3)}$ と略同一傾向である。

\section{IV. 考 察}

1）旧式焼酎，特に琴取焼酎の品位又は収得歩合を重点的に製造諸元を調查し，適確に把握するのは実際 水はなかなか困難である。通常旧式焼酩は

(1) 一仕込分を分割仕込する。

最近は 10 石容のコンクリート槽もあり, 又 $22 \sim 23$ 石容の木桶仕込も岕るが, 醪取焼酎のほとんぞが 3

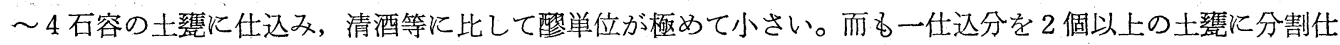
込するのが普通である。従つて同一仕込分とはい光仕込甕が異るので, 厳密に見れば温度経過, 最高温度, 最高までの時間，更に熟成までの日数は必ずしも同一ではない。

（2）蒸溜は少くも一仕込分或いはそれ以上を合併して行う。

通常土蒦 2 本以上の熟成慗を合併蒸溜する。

（3）一検定分界は少くも一蒸溜区分以上を合併査定する。

一検定分界は多い時には 10 蒸留区分以上を合併査定するのが常であるから，一仕込一甕一蒸溜区分一検 定分界といらょうなことは実地的には全く見られない。

以上より一次, 二次仕込の製造条件或いはその経過を把捯するのは非常に難かしい。

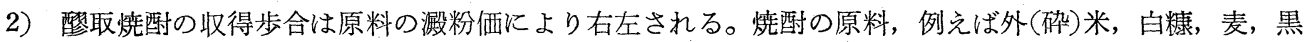
糖, 更に高粱, 栗, 王蜀㯟等雑糓類の澱粉価は品種, 産地, 収穫時期等によつて大差はないが, 生芋は前調 査 ${ }^{1)}$ 亿依れば管内平均 $27.67 \%$, 最高 31 , 最低 21 で可成の差異がある。本報でも生芋の澱粉価を 27 と したので, 最高価との差は $4 \%$ ，最低との差は $6 \%$ ，最高最低とは $10 \%$ のひらきがある。従つて収得歩合 $80 \%$ と言党ども，若しその供試焼酎に使用した生芋の澱粉価が最高の 31 であつたとすれば，収得歩合は 73 \%となり，表示歩合より $7 \%$ す少いことになる。

併し実際的には供試した個々の芋焼酎について，仕込んだ生芋の正確なる澱粉価を，或いは醪中の総有効 成分を適確に知る事は旧式焼酎工場の設備の現況からしては難かしく，恐らく可能なことではない。

3）更に烧酎の収得步合は熟成醪や製品焼酎の容量測定が正確であるとしても，原料払出の正確度は仲々 完全を期しがたい。

4）本調查には製造工程中の製造 loss 等は見込んでない。

5）詳細に見れば本調査は以上の如き二，三の欠点が当然指摘されるが，最近の旧式焼酎の実際の傾向を 知得すべく，又その概況を把握するためには，かかる欠点やそれによる数字のフレも止むを得ないるのと私 考される。 
本調査に御協力いただいた熊本国税局管内旧式焼酎の製造工場，局鑑定官室ならびに税務署の方々，更に 種々有益な御助言をたまわつた国税庁醸造試験所野白喜久雄技官に深謝します。

（熊本国税局鑑定宮室）

\section{文 献}

1) 加藤 百一: 䤑協 $51,100($ 昭31)

2) 山田 正一: 酒類工業, $287 \sim 320$ 頁 (昭 24 )

3) 加藤 百一: 醸協 51，258(昭31)

4) 小原 篇: 䁔協 36, 257(昭16)

5）焼酎研究会：醸協 40,33(昭20)
6）武藤始太郎，井原辰男：醸協 40，60(昭20)

7) 佐治 恒二：䁔協 41，58(昭21)

8）芝田喜三代：焼酎製造の実際，118頁(昭24)

9）野白喜久雄：醸協 51，808(昭31)

10）木村 輝治：醸協 47, 79(昭27)

\title{
清酒の一蛋白混濁質物の分離
}

\author{
林辺礼一 \\ (昭和 31 年 11 月 29 日受理)
}

清酒の白ボケはここ数年来に於ける清酒業関係者の大きな問題である。随つて近年これに関する報告, 論 説も亦多くなつている。清酒の混濁と言う事はアル添が一般的に行われる以前にも在つた事は当時の報告に も散見せられる処から充分推察される。然し乍ら現在の実験考察の傾向はアル添の功罪中罪の主たるものと して白ボケをとり上げているよらである。とは言つてもアル添・未分解・白ボケが直結すべきかどうかについ ては未だ或る種の決定をなすべき段階には到つていない。麦酒1の混濁の中グリチン混濁等は含有成分の平 衡状態が温度の急変, 激しい動摇, 強い光線により破られるためにグリチンが遊離析出して生ずるとされて いる。又同時に糊精, 真正蛋白による混濁もあるが, 或る種の金属イオン $(\mathrm{Pb} \cdot \mathrm{Ni} \cdot \mathrm{Zn}$ は強く, $\mathrm{Cu} ・ \mathrm{Al}$ も作用する）によつても惹起される場合のある事も報ぜられている。清酒に於ても混濁の発生原因としては 所謂末分解概念の他に種々の考え方を導入すべきであろらと思われる。

混濁質物の本体については市川氏等 $\left.{ }^{2}\right)$ 及び寺本氏等3)によつて各々独立に略々同じ内容の発表がなされて いる。即ち本体と考えられるものを加水分解して分析した結果, 窒素物と炭水化物が半々位宛で, しかし炭 水化物中には酵母菌体から由来すると考号れるマンノーズ等が含まれている事を確認している。市川氏等 は或る種酵素によつて沈澱する成分をみつけ，寺本氏は金属イオンが混濁促進効果を有する事等を併せて報 ぜられているが，何れも混濁質の本体として捕えられたものが理化学的に単一成分のものでない事について は一致しているょうである。

筆者は一昨年 (昭和 29 酒造年度) の醸出酒について混濁成分と認められるるのを得たのでそれに関する 試験を行つてきたところ, 前述の両報告と異るような結果を得たので混濁質物の一種としてとり上げてみた 次第である。

杤木県の一造家に於て早期比較的辛口酒を多く出荷した為に甘口酒が多くなり䠉蔵酒をそのまま出荷す るという事が困難となつてきたので救済用として秋季にアル添を行い(約 27 石の清酒に $30 \%$ アルニール 約 15 石）全庫内酒の清酒メートルの調整を図つた訳である。その前後の成分は次表の通り。その後出荷を

$\begin{array}{ccccc} & & \text { 清酒メートル } & \text { アルュール } & \text { 総酸 } \\ \text { 混 和 } & \text { 前 } & (-) 8.0 & 19.8 & 2.3 \\ \text { 混 和 後 } & (+) 14.5 & 24.5 & 1.8\end{array}$

続けた処タンクの底部に異常に多い暗褐色抳状の沈澱をみた。たまたまその酒が他の酒に比べて大変テリの 良い処からこれを混濁に関係のある成分と推定した訳である。このものは酸性側では不透明に濁つているが アルカリ性では透明にとける。水溶液 (懸濁液) は著しく泡持ちが良く, 泡はシャボン玉様の干渉に上り呈 色を示す。又冷蔵庫内に静置しておくと三昼夜位できれい清酒の上澄を生ずるが加水したもの（アルコー ル約 $15.5 \%$ ）国じ条件でも一部黄褐色の沈澱をみるのみで相当の白濁を残す。この事から今回とりだし た沈停物は清酒成分の，殊にアルコール分の濃淡に関して概略二分できる事になる。

2 升の沈澱物から静置して更に約 9 合の清澄部を除き, 次いで遠心分離により沈澱部約 200 站を得た。こ 